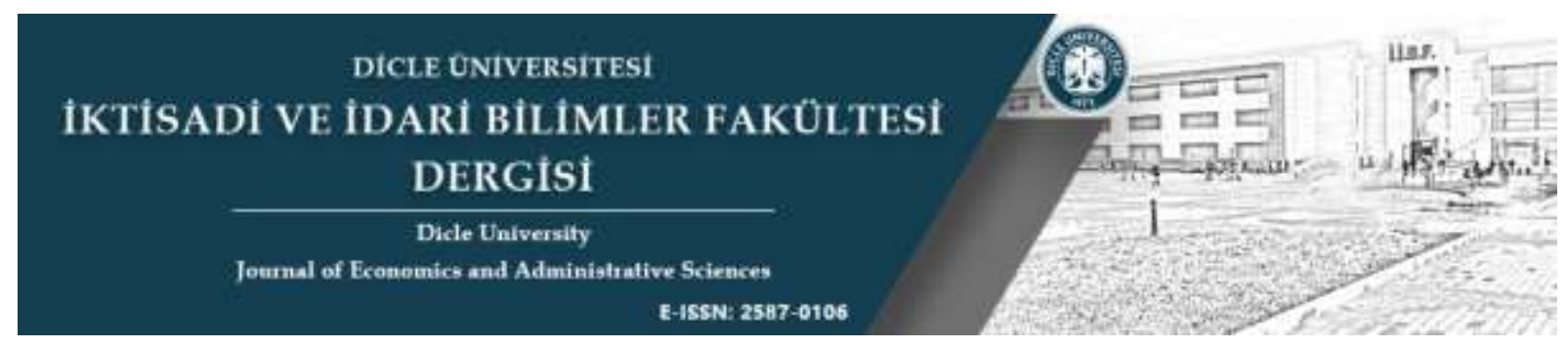

Cilt / Volume: 11, Sayı /Issue: 22, Sayfalar / Pages: 281-294

Araştırma Makalesi / Research Article

Received / Alınma: 14.07.2021

Accepted / Kabul: 12.08.2021

\title{
HASTALARIN HAK VE SORUMLULUKLARI KONUSUNDAKİ BİLGİ DURUMLARI: DIYYARBAKIR ÖRNEĞİ
}

\author{
Mümtaz KORKUTAN ${ }^{1}$ \\ Ümit IŞIK ${ }^{2}$
}

\section{$\ddot{\boldsymbol{O}} z$}

Diyarbakır ilinde hizmet veren Gazi Yaşargil Eğitim ve Araştırma Hastanesine başvuran 18 yaş üstü hastaların hasta hakları ve sorumluluklarıyla ilgili bilgi düzeylerini tespit etmek maksadıyla yapılmış tanımlayıcı bir araştırmadır. Gazi Yaşargil Eğitim ve Araştırma hastanesine başvuran 18 yaş üstü, akli dengesi yerinde olan ve anket sorularına cevap verebilecek 400 kişi basit ve rastgele örneklem yöntemiyle seçilmiş olup araştırmaya dahil edilmiştir. Araştırma için kullanılan anket formunun soruları 01.08.1998 yılında Resmi Gazete yayımlanan 23420 Sayılı Hasta Hakları Yönetmeliği başta olmak üzere ilgili literatür taranıp hazırlanmıştır. Anket formu araştırmacı tarafından yüz yüze anket uygulama yöntemiyle uygulanmıştır. Araştırma verileri frekans ve yüzde hesaplamalarıyla değerlendirilmiştir. Hastaların \%55'i Hasta Hakları Yönetmeliğini bilmektedir. Hastalar, \%95 ile ziyaret ve refakatçi bulundurma hakkı, \%86 ile tıbbi müdahale için hastadan rıza alınma hakkı, \%44 ile sağlık hizmetlerinden adalet ve hakkaniyete uygun olarak faydalanma hakkı, \%50 ile tıbbi gereklilikler dışında müdahale yapılamayacağı hakkı olduğunu bilmektedir. Yönetmelikte geçen hasta sorumluluklarıyla ilgili hastaların bilgi düzeylerinin genel olarak \%70 üzerinde olduğu görülmüştür. Eğitim ve Araştırma hastanesine başvuran hastaların hasta hakları ve sorumluluklarıyla ilgili bilgi düzeylerinin iyi durumda olduğu konuyla ilgili eksik olan hususlar içinde hastalara yönelik bilinçlendirme çalışmalarının yapılması gerektiği düşünülmektedir.

Anahtar Kelimeler: Hasta, Hasta Hakları, Hasta Sorumlulukları.

Jel Kodları: I10, I19, H51.

${ }^{1}$ Öğr. Gör., Bitlis Eren Üniversitesi Sosyal Bilimler MYO, Yönetim ve Organizasyon Bölümü, Sağlık Kurumları İşletmeciliği Pr, e-posta: Mkorkutan@ beu.edu.tr, ORCID: 0000-0001-7588-6836.

${ }^{2}$ Y.L. Öğrencisi, Fırat Üniversitesi, Sosyal Bilimler Enstitüsü, Sağlık Yönetimi ABD, e-posta: pasurlu9999@gmail.com, ORCID: 0000-0003-2704-9376.

\section{Atıf/Citation}

Korkutan, M., \& Işı, Ü. (2021). Hastaların hak ve sorumlulukları konusundaki bilgi durumları: Diyarbakır örneği. Dicle Üniversitesi İktisadi ve İdari Bilimler Fakültesi Dergisi, 11(22), 281-294. 


\title{
INFORMATION STATUS OF PATIENTS ABOUT THEIR RIGHTS AND RESPONSIBILITIES: THE EXAMPLE OF DIYARBAKIR PROVINCE
}

\begin{abstract}
This is a descriptive study conducted to determine the level of knowledge about the rights and responsibilities of patients over the age of 18 who applied to Gazi Yaşargil Training and Research Hospital serving in Diyarbakir province for medical purpose. 400 people over the age of 18 who were admitted to Gazi Yaşargil Training and Research Hospital, mentally rational and have ability to answer survey questions were selected by a simple and random sample method and included in the study. Questions of the questionnaire used for research has been prepared by scanning relevant literature, especially the Patient Rights Regulation No. 23420 published in the Official Gazette on 01.08.1998, The survey form was applied by the researcher with face-to-face survey application method. Research data was evaluated by using frequency and percentage calculations. 55\% of patients know the Patient Rights Regulation. 95\% of patients know that they have the right to have visitor and/or companion, $86 \%$ of patients know that they have the right that there must be a consent from the patient for medical intervention, $44 \%$ of the patients know that they have the right to benefit from medical services in accordance with justice and fairness, $50 \%$ of the patients know that they have the right not to be intervened other than medical requirements. In general, the level of knowledge of patients about patient responsibilities covered in the regulations was above $70 \%$. It is thought that the patients who applied to the Training and Research Hospital have a good level of knowledge about the rights and responsibilities of the patients and that awareness raising activities should be carried out for the patients regarding the missing issues
\end{abstract}

Keywords: Patient, Patient Rights, Patient Responsibilities.

Jel Codes: I10, I19, H51.

\section{GíRiş}

İnsanoğlu dünya tarihi boyunca temel olarak önce yaşamak ve devamında sağlığını korumak amacıyla hep bir mücadele göstermiştir. Sağlıklı yaşamak insanların temel amacı olmuştur. İnsanlar gelişen ve olgunlaşan hayat mücadelesiyle birlikte toplumlar içinde yaşamayı öğrenmiş ve dolayısıyla toplum içinde sosyal bir birey olduğunun farkına vardığında da bazı tanımlar, kavramlar geliştirmiştir. Bu kavramlardan bazıları; hak, sağglık hakkı, hasta hakları gibi karşımıza çıkmaktadır (Hatırnaz, 2007, s. 10-20). Kişinin hakları genel anlamda insan hakları evrensel bildirgesinde yayınlanmıştır. Dünya genelinde kabul gören bu bildirgenin kişilerin sağlığı ile ilgili geçen maddesi "ırk, dil, din, politik inanç, sosyo-ekonomik durum ayrımı gözetmeden herkesin erişebilecek en üst düzeyde sağlıklı olma temel hakkına sahip olduğu” şeklindedir. Hiçbir fark gözetilmeden hak olarak kabul edilen sağlıklı yaşama hakkı beraberinde kişilerin hasta haklarını da doğurmaktadır. Literatür genel anlamda hasta haklarını kişilerin hizmet aldığı sağlık kurumları ile sağlık çalışanları arasındaki ilişkilerinde sahip olduğu tüm haklar olarak tanımlamaktadır (Özlü, 2005, s. 14-21). Hasta hakları diğer haklardan ziyade sadece insana has bir hak olması, dolayısı ile 3. Kuşak insan hakları içinde yer almaktadır. Ayrıca hasta hakları, insan hakları ve değerlerinin sağlık hizmeti veren kurum ve kuruluşlarında yani sağlık hizmetlerinin alımında uygulanmasını kapsamaktadır. Bu haklar 
temel olarak; maksimum düzeyde sağlıklı bir sağlık hizmeti alma olmak üzere, kişisel mahremiyet, tıbbi işlemlerde onay alma, saygı görme, gizliliğe önem verme, bakım ve tedavinin devamlılığının sağlanması gibi başlıkları içermektedir (Oğuz, 1997, s. 50-55; Özcan, 2010, s. 40).

Hasta haklarının tarihsel süreç içerisinde ortaya çıkışı ve gelişimi birçok durumda olduğu gibi teknolojinin gelişimi ile bilginin karmaşıklaşması ve tabiplerin hasta üzerindeki gücünün artması gibi nedenlerle beraber ortaya çıkmıştır. Bu gibi nedenlere bağlı olarak hasta hakları gün geçtikçe gelişim göstermiştir. Hasta haklarının doğal olarak insan haklarından ortaya çıktığı bilinmektedir. İnsan haklarının ortaya çıkışı dünya genelinde hak ihlallerinin üst düzeyde olduğu dönemlerde olmuştur. İnsanoğlunun varlığından beri konuşulan ve ihtiyaç duyulan bu kavram uluslararası anlamda ilk defa Birleşmiş Milletler tarafından 10 Aralık 1948 yılında yayınlanan İnsan Hakları Evrensel Beyannamesi ve 4 Kasım 1950 yılında yayınlanan Avrupa İnsan Hakları Sözleşmesi ile gündeme gelmiştir (Engin, 2014, s. 215). Hasta hakları alanı için ilk sayılan bu raporların uluslararası anlamda sistematik bir sürece girmesi yirmi yıldan fazla olmuştur.

Amerika Birleşik Devletleri'ndeki bazı hekimlerin ortaya attıkları teze göre, hastanelerde yatan hastaların yatışları süresince bazı haklarının ortaya çıktığı bu hakların etik konulardan ve yasal haklardan meydana geldiği vurgulanmıştır. Hekimlerin bu tezi 1972 yılında Amerika Hastanesi Birliğinin Hasta Hakları Bildirisi’ne dönüştürülerek yayınlanmıştır (Johnstone, 1989, s. 29-34). Bu bildirge uluslararası hasta hakları alanında yayınlanan ilk bildirge olmuştur. Hekimlerin öncülük ettiği bu bildirgeden yola çıkarak hasta haklarının temel olarak hekimler ile hastalar arasındaki etkileşimden kaynaklandığı söylenebilir. Buradaki temel etken kişilik haklarının çiğnenmesinin önlenmesidir. Bu hakkın gereği kişilik haklarına zarar verilecek tutum ve davranışlardan hekimlerin kaçmasıdır (Bozkuş, 1997, s. 8). ABD'deki hekimlerin yayınladığı bu bildirge ile hastaların sağlık çalışanlarına karşı hakları ilk yasal belge ile güvence altına alınmıştır.

Hasta hakları kapsamı ve temelleri İnsan Hakları Evrensel Beyannamesi’nde olduğu gibi birçok uluslararası bildirge, beyanname ve sözleşmelerde de belirlenmiştir. Uluslararası belgelerden sonra hasta haklarıyla ilgili kuralları düzenleyen özel belge ve sözleşmeler de oluşmuştur. Lizbon Hasta Hakları Bildirgesi 1981 yılında Dünya Tabipler Birliği tarafından kabul edilip yayınlanan ilk özel belgedir. Lizbon Bildirgesi hasta haklarını daha çok hekimlik kuralları başlığı altında düzenlendiğinden eksiklikleri vardır. Amsterdam'da 1994 yılında kabul edilen Avrupa Hasta Hakları bildirgesi ve 1995 yılında kabul edilen Bali Bildirgesi'yle 
bu eksiklikler giderilmeye çalışılmıştır. “Avrupa'da Hasta Haklarının Geliştirilmesi Bildirgesi” Amsterdam'da 1994 y1lında kabul edilmiştir (Hatun, 1997, s. 15). Bu bildirgenin kapsamı 1995 yılında Dünya Tabipler Birliği tarafından genişletilerek "Bali Bildirgesi” olarak kamuoyuyla paylaşılmıştır. Kısacası "Hasta Hakları Şartı” olan Hasta Hakları Avrupa Statüsü Sözleşmesi 2002 yılında Roma’da kabul edilmiştir. Birçok ülkede hasta haklarıyla ilgili özel kanunlar olmamasına rağmen Danimarka, İsrail ve Arjantin gibi bazı ülkelerde hasta haklarıyla ilgili kanunlar bulunmaktadır (Tengilimoğlu vd., 2020, s. 463).

Hasta hakları konusunda Dünyadaki gelişmeler hızla yayılmış olup ülkemiz de bu konuda geride kalmamıştır. Mevzuatta, hasta haklarına ilişkin düzenlemeler incelendiğinde tüm taraflarca (hasta, hasta yakını, sağlık çalışanı vs.) bilinen, istenen, kabul edilen, talep edilen, eksiksiz uygulanan ve denetlenen detaylı, açık ve anlaşılır kurallar yoktur. Hasta haklarının bir bölümünün genel hukuksal düzenlemelerle belirlenmektedir. Ülkemizde hasta haklarına ilişkin düzenlemeler 1928 yılında çıkmış olan Tıp Mesleğinin Uygulanmasına İlişkin bir kanunda yer almaktadır ve 1999 yılında değiştirilmiştir. Bu kanun, Tıp Meslek Ahlak İlkeleri olarak da bilinen ve 1961 yılında çıkarılan “Tıbbi Deontoloji Nizamnamesi”nde de yer almaktadır. Bununla beraber 1979 yılında kabul edilen "Organ ve Doku Alınması, Aşılanması ve Nakli Hakkında Kanun", 1983 yılında resmen kabul edilen "Nüfus Planlaması Hakkında Kanun” ve 1993 yılında kabul edilen İlaç Araştırmaları Hakkında Yönetmelik” de hasta haklarıyla ilgili bazı hükümler içermektedir (Civaner \& Okuyan, 1999, s. 23-174; Demirhan, 1996, s. 35-50).

Türkiye Cumhuriyeti'nin taraf olduğu uluslararası sözleşmelerin etkisiyle bugüne kadar hasta haklarıyla ilgili yaptığı en büyük gelişme, Ağustos 1998 yılında kabul edilen Hasta Hakları Yönetmeliği'dir (Bostan, 2007, s. 15). Bu yönetmelik Türkiye'de hasta haklarıyla ilgili mevcut olan bazı yasaları, tüzükleri ve yönetmeliklerin tamamını kapsamaktadır. Hasta Hakları Yönetmeliği dokuz bölüm ve 51 maddeden oluşmaktadır.

Hasta haklarına ilişkin yukarıda belirtilen gelişmelerin hemen akabinde yani 2000'li yılların başında devlet çapında yeni gelişmeler yaşanmıştır. Bu gelişmelerin başında Sağlıkta Dönüşüm Programı ile uyumlu olan ve Ekim 2003 yılında yayımlanan "Sağlık Tesislerinde Hasta Hakları Uygulamalarına İlişkin Yönerge” gösterilebilir. Bu Yönerge ile hasta ve hasta yakınlarının yasada belirlenmiş haklarını fiilen kullanabilmeleri, hastaların tedavi süreci boyunca ilgililer tarafından bilgilendirilmeleri, kişilerin hak ihlallerine karşı korunabilmeleri ve gerektiği durumlarda kişilerin hukuki korunma yollarını fiilen kullanabilmeleri amaçlanmıştır. Yönergenin kabul edilmesiyle birlikte 60 hastanede başlatılan Hasta Hakları 
Uygulamaları bir yıl içinde 131 hastanede uygulanmıştır. "Sağlık Tesislerinde Hasta Hakları Uygulamalarına İlişkin Yönerge" 25 Nisan 2005 tarihinde yürürlükten kaldırılarak yerine “Hasta Hakları Uygulama Yönergesi” yürürlüğe konulmuştur (Çotur, 2013, s. 25). Bu şekilde hasta hakları daha da yasal bir boyut kazanmış olup önemi artmıştır.

Hasta hakları yönetmeliği genel olarak hak ve haklar dışında hastaların sorumlulukları üzerinde detaylı konuları kapsamaktadır. Sorumluluk, birey veya bireylerin başka bireylere veya kuruluşlara karşı üstlenmesi gereken görevdir. Her bireyin hasta olduğu ve herhangi bir sağlık kuruluşuna başvurduğu andan itibaren sahip olması gereken haklar yanında uyması gereken sorumluluklar da vardır. Hasta Hakları Yönetmeliği’nin sekizinci bölümünde hastaların üstlenmesi gereken sorumluluklar belirtilmiştir. Hasta hakları; hastaların, hasta yakınlarının ve tüm sağlık çalışanlarının öncellikli olarak önem vermesi gereken kuralları içermektedir. Hasta hakları kurallarının uygulanması konusuna en çok hastalarla irtibat içinde olan hekimler, hemşireler ve diğer sağlık çalışanları dikkat etmelidirler. Tüm sağlık çalışanları hizmet sunumunun başından sonuna kadar hastalara saygılı davranarak güvenilir bir hizmet sunmak durumundadırlar. Ayrıca hasta ve hasta yakınları da hizmet alma aşaması boyunca tüm çalışanlara karşı saygılı davranmak ve sorumluluklarını eksiksiz bir şekilde yerine getirmek zorundadırlar.

Hasta hak ve sorumluluklarının bilinmesi sağlık kurumlarında süreçlerin sağlıklı bir şekilde işlenmesi için çok önemlidir. Sağlık kurumlarına başvuran tüm hastaların kendi hak ve sorumluluklarını bilmesi çok zor görünmektedir. Literatür çalışmalarına bakıldığında hasta hak ve sorumluluklarını temel alan çalışmaların çok az olduğu görülmektedir. Bu çalışmayla hasta hak ve sorumlulukları konusunda tüm toplumda farkındalık oluşturulma gaye edinmiştir. Farkındalığın artmasıyla sağlık çalışanlarına düşen yükün azalacağı dolayısıyla daha kaliteli bir sağlık hizmetinin verilmesi olasıdır. Tüm bunlardan yola çıkarak Diyarbakır Gazi Yaşargil Eğitim ve Araştırma Hastanesine başvuran hastaların, hasta hakları ve sorumlulukları konusunda bilgi durumları tespit edilmeye çalışılmıştır.

\section{GEREÇ VE YÖNTEM}

Bu çalışma 14.09.2020 tarihinde Bitlis Eren Üniversitesinden alınan Etik Kurul izni (BEÜ Etik Kurulunun 06/10/2020 tarih ve 2020/08-III sayılı kararı) ile Diyarbakır Gazi Yaşargil Eğitim ve Araştırama hastanesinde yapılmıştır. Diyarbakır Sağlık Bilimleri Üniversitesi Gazi Yaşargil Eğitim ve Araştırma Hastanesine başvuran tüm hastalar araştırmanın evrenini oluşturmuştur. Araştırmanın örneklemi 21 Eylül 2020 tarihi ile 30 Eylül 2020 tarihleri arasında hastaneye başvuran, 18 yaş ve üstü psikiyatrik bir rahatsızlığı olmayan, araştırma 
sorularına gönüllü bir şekilde cevap vermek isteyen ve araştırmacı tarafından iletişim kurulabilen 400 kişiden oluşmaktadır. Araştırma için oluşturulan anket formu 01.08.1998 yılında Resmi Gazete yayımlanan 23420 Sayılı Hasta Hakları Yönetmeliği başta olmak üzere ilgili literatür (Eksen vd., 2004, s. 1-12; Günay vd., 2007, s. 307; Ünsal vd., 2011, s. 27-40) taranıp hazırlanmıştır. Anket formu tanıtıcı özellikler ile ilgili 6, hasta hakları farkındalığı ve bilgilendirilme durumu ile ilgili 4 , hasta hakları hakkında bilgi durumları ile ilgili 18, hasta sorumluluklarını bilme durumu ile ilgili 7 soru olmak üzere toplam 34 sorudan oluşmaktadır. Hastalar bilgi düzeylerinin ölçüldüğü sorulara yanıt olarak; "Biliyor, Kısmen Biliyor ve Bilmiyor" şeklinde cevap vermiştir. Toplanan veriler bilgisayar ortamına aktarılmış olup verilerin analizi frekans ve yüzdelik dağılım hesaplamalarıyla yapılmıştır.

\section{BULGULAR}

Hastaların tanıtıcı özelliklerinin dağılımı Tablo 1'de gösterilmiştir.

Tablo 1. Hastaların Tanıtıcı Özelliklerinin Dağılımı

\begin{tabular}{|c|c|c|c|}
\hline \multicolumn{2}{|c|}{ Tanıtıcı özellikler } & Sayı & $\%$ \\
\hline \multirow{4}{*}{ Yaş } & $18-25$ & 152 & 38.0 \\
\hline & $25-35$ & 104 & 26.0 \\
\hline & $35-45$ & 68 & 17.0 \\
\hline & 45 ve üstü & 76 & 19.0 \\
\hline \multirow{2}{*}{ Cinsiyet } & Kadın & 200 & 50.0 \\
\hline & Erkek & 200 & 50.0 \\
\hline \multirow{5}{*}{ Eğitim Durumu } & Okuryazar Değil & 24 & 6.0 \\
\hline & Okuryazar & 20 & 5.0 \\
\hline & İlköğretim Mezunu & 72 & 18.0 \\
\hline & Lise Mezunu & 116 & 29.0 \\
\hline & Üniversite Mezunu & 168 & 42.0 \\
\hline \multirow{6}{*}{ Meslek } & İşsiz & 144 & 36.0 \\
\hline & Esnaf, Çiftçi, İşçi & 52 & 13.0 \\
\hline & Ev Hanımı & 84 & 21.0 \\
\hline & Memur & 64 & 16.0 \\
\hline & Emekli & 24 & 6.0 \\
\hline & Serbest Meslek & 32 & 8.0 \\
\hline \multirow{4}{*}{ Gelir Durumu } & $0-1000 \mathrm{TL}$ & 236 & 59.0 \\
\hline & $1000-2000 \mathrm{TL}$ & 64 & 16.0 \\
\hline & $2000-3000 \mathrm{TL}$ & 60 & 15.0 \\
\hline & $3000-4000 \mathrm{TL}$ & 24 & 6.0 \\
\hline
\end{tabular}




\begin{tabular}{|l|l|c|c|}
\hline & 4000 TL ve Üstü & 16 & 4.0 \\
\hline \multirow{3}{*}{ Yaşanılan Yer } & Köy & 48 & 12.0 \\
\cline { 2 - 4 } & İlçe & 36 & 9.0 \\
\cline { 2 - 4 } & İl Merkezi & 316 & 79.0 \\
\hline
\end{tabular}

Çalışmaya katılanların \%38'i 18-25 yaş aralığında, \%50'si kadın, \%42'si üniversite mezunu hastalardır. Çalışmaya katılanların \%36'sı işsiz, \%59'unun geliri 1000 TL ve altında olduğu ve \%79’unun yaşadığı yer il merkezi olduğunu belirtmiştir (Tablo 1).

Hasta hakları konusunda farkındalık durumunun dağılımı Tablo 2'de yer almaktadır.

Tablo 2. Hasta Hakları Konusunda Farkındalık ve Bilgilendirme Durumunun Dağılımı

\begin{tabular}{|c|c|c|c|c|}
\hline \multirow{2}{*}{ Farkındalık } & \multicolumn{2}{|c|}{ Evet } & \multicolumn{2}{|c|}{ Hayır } \\
\hline & Sayı & $\%$ & Sayı & $\%$ \\
\hline 1. Hasta Hakları Biriminden haberdar olma & 204 & 51 & 196 & 49 \\
\hline $\begin{array}{l}\text { 2. Hasta hakları konusunda bilgilendirilme durumu* } \\
\text { Bilgilendiren; } \\
\checkmark \quad \text { Hekim } \\
\checkmark \quad \text { Hemşire } \\
\checkmark \quad \text { Sağlık Memuru } \\
\checkmark \quad \text { Radyolog }\end{array}$ & $\begin{array}{r}56 \\
36 \\
12 \\
4 \\
4\end{array}$ & 14 & 344 & 86 \\
\hline 3. Hasta Hakları Yönetmeliğinden haberdar olma durumu & 220 & 55 & 180 & 45 \\
\hline
\end{tabular}

* Dağılım bilgilendirilen hasta verileri üzerindendir.

Hastaların \%51'i hasta hakları biriminden haberdar olduğunu, \%14'ü hastane çalışanları tarafından hasta hakları konusunda bilgilendirildiğini ve \%55'i de Hasta Hakları Yönetmeliğini önceden bildiğini belirtmiştir (Tablo 2). 400 hasta üzerinden yapılan araştırmada, hastaların \%14'ü hastanede çalışanlar tarafından hasta hakları konusunda bilgilendirdiği belirtmiştir. Yapılan toplam bilgilendirmelerin \%64.2'si (36) hekimler tarafindan olduğu görülmektedir.

Hastaların hasta hakları konusunda bilgi durumlarının dağılımı Tablo 3 'te görülmektedir. 
Tablo 3. Hastaların Hasta Hakları Konusundaki Bilgi Durumlarının Dağılımı ( $n=400)$

\begin{tabular}{|c|c|c|c|c|c|c|}
\hline \multirow[t]{2}{*}{ Hasta Hakları Konusunda Bilgi } & \multicolumn{2}{|c|}{ Evet } & \multicolumn{2}{|c|}{ Hayır } & \multicolumn{2}{|c|}{$\begin{array}{c}\text { Fikrim } \\
\text { Yok }\end{array}$} \\
\hline & Sayı & $\%$ & Sayı & $\%$ & Sayı & $\%$ \\
\hline $\begin{array}{l}\text { 1. Sağlık Hizmetlerinden Adalet ve Hakkaniyete Uygun Olarak } \\
\text { Faydalanma hakkına ilișkin bilginiz var mı? }\end{array}$ & 176 & 44 & 212 & 53 & 12 & 3 \\
\hline $\begin{array}{l}\text { 2. Sağlık hizmetleri konusunda bilgi alma ve isteme hakkına sahip } \\
\text { olduğunuzu biliyor musunuz? }\end{array}$ & 312 & 78 & 80 & 20 & 8 & 2 \\
\hline $\begin{array}{l}\text { 3. Sağlik kuruluşunu seçme veya değiştirme hakkına sahip } \\
\text { olduğunuzu biliyor musunuz? }\end{array}$ & 296 & 74 & 100 & 25 & 4 & 1 \\
\hline $\begin{array}{l}\text { 4. Personeli tanıma, seçme ve değiştirme hakkına sahip } \\
\text { olduğunuzu biliyor musunuz? }\end{array}$ & 208 & 52 & 176 & 44 & 16 & 4 \\
\hline $\begin{array}{lllll}\text { 5. Öncelik sırasının belirlenmesini isteme hakkına sahip } \\
\text { olduğunuzu biliyor musunuz? }\end{array}$ & 244 & 61 & 152 & 38 & 4 & 1 \\
\hline $\begin{array}{l}\text { 6. Tibbi gereklere uygun teşhis, tedavi ve bakım isteme hakkınızın } \\
\text { olduğunu biliyor musunuz? }\end{array}$ & 240 & 60 & 140 & 35 & 20 & 5 \\
\hline $\begin{array}{l}\text { 7. T1bbi gereklilikler dışında müdahale yapılamayacağını ve } \\
\text { talepte bulunamayacağınızı biliyor musunuz? }\end{array}$ & 200 & 50 & 180 & 45 & 20 & 5 \\
\hline $\begin{array}{l}\text { 8. Personelden tıbbi özen göstermesini isteme hakkına sahip } \\
\text { olduğunuzu biliyor musunuz? }\end{array}$ & 280 & 70 & 108 & 27 & 12 & 3 \\
\hline $\begin{array}{l}\text { 9. Kendinize ait kayıtları inceleme ve kayıtlarda bir eksik veya } \\
\text { hata varsa bunu düzeltmeye hakkınız olduğunu biliyor } \\
\text { musunuz? }\end{array}$ & 292 & 73 & 104 & 26 & 4 & 1 \\
\hline $\begin{array}{l}\text { 10. Hasta mahremiyetine özen gösterilmesi hakkınızın olduğunu } \\
\text { biliyor musunuz? }\end{array}$ & 336 & 84 & 64 & 16 & 0 & 0 \\
\hline $\begin{array}{l}\text { 11. Hastanın rızası olmadan herhangi bir tıbbi müdahale } \\
\text { yapılamayacağına dair hakkınızın olduğunu biliyor musunuz? }\end{array}$ & 344 & 86 & 48 & 12 & 8 & 2 \\
\hline $\begin{array}{l}\text { 12. Hastaya ait bilgilerin gizli tutulmasını bir hak olduğunu biliyor } \\
\text { musunuz? }\end{array}$ & 312 & 78 & 80 & 20 & 8 & 2 \\
\hline $\begin{array}{l}\text { 13. Hastaların tedaviyi reddetme ve durdurma hakkının olduğunu } \\
\text { biliyor musunuz? }\end{array}$ & 336 & 84 & 40 & 10 & 24 & 6 \\
\hline $\begin{array}{l}\text { 14. Hastaların güvenli ortamda sağlık hizmeti alma hakkına sahip } \\
\text { olduğunuzu biliyor musunuz? }\end{array}$ & 324 & 81 & 72 & 18 & 4 & 1 \\
\hline 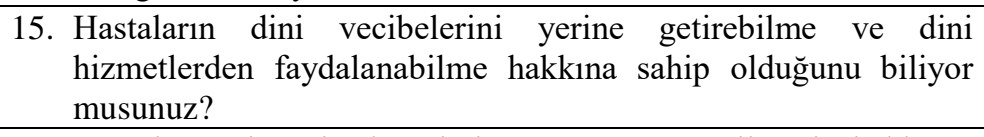 & 304 & 76 & 80 & 20 & 16 & 4 \\
\hline $\begin{array}{l}\text { 16. Hastaların insani değerlerine saygı gösterilmesi hakkının } \\
\text { olduğunu biliyor musunuz? }\end{array}$ & 340 & 85 & 56 & 14 & 4 & 1 \\
\hline $\begin{array}{l}\text { 17. Hastaların ziyaret ve refakatçi bulundurma hakkına sahip } \\
\text { olduğunuzu biliyor musunuz? }\end{array}$ & 380 & 95 & 20 & 5 & 0 & 0 \\
\hline $\begin{array}{l}\text { 18. Müracaat, şikâyet ve dava hakkınızın olduğunu biliyor } \\
\text { musunuz? }\end{array}$ & 332 & 83 & 60 & 15 & 8 & 2 \\
\hline Ortalama & 292 & 73 & 98.5 & 24.6 & 9.5 & 2.4 \\
\hline
\end{tabular}

Hastaların en çok \%95 oranında ziyaret ve refakatçi bulundurma, \%86 oranında tıbbi müdahale için hastadan rıza alınması \%85 oranında hastaların insani değerlerine saygı gösterilmesi \%84-oranında mahremiyet ve tedaviyi reddetme ve \%83 oranında müracaat, şikâyet ve dava hakkını bildikleri saptanmıştır. Hastaların en az \%44 oranında sağlık hizmetlerinden adalet ve hakkaniyete uygun olarak faydalanma, \%50 oranında tıbbi 
gereklilikler dışında müdahale yapılamayacağını, \%52 oranında personeli tanıma, seçme ve değiştirme, $\% 60$ oranında teşhis, tedavi ve bakım isteme ve $\% 61$ oranında öncelik sırasının belirlenmesini isteme hakkını bildikleri saptanmıştır (Tablo 3).

Hastaların hasta sorumluluklarını bilme konusunda bilgi durumlarının dağılımı Tablo 4'te görülmektedir.

Tablo 4. Hastaların Sağlık Kurumlarındaki Sorumluluklarını Bilme Durumlarının Dağılımı

\begin{tabular}{|c|c|c|c|c|c|c|}
\hline \multirow[t]{2}{*}{ Sağlık Kurumlarındaki Sorumluluklar } & \multicolumn{2}{|c|}{ Evet } & \multicolumn{2}{|c|}{ Hayır } & \multicolumn{2}{|c|}{$\begin{array}{c}\text { Fikrim } \\
\text { Yok }\end{array}$} \\
\hline & Sayı & $\%$ & Sayı & $\%$ & Sayı & $\%$ \\
\hline $\begin{array}{l}\text { 1. Başvurduğumuz sağlik kurum ve kuruluşlarının kural } \\
\text { ve uygulamalarına uygun davranma ve katılımcı bir } \\
\text { yaklaşımla teşhis ve tedavi ekibinin bir parçası olduğu } \\
\text { bilinciyle hareket etmemiz gerektiğini biliyor } \\
\text { musunuz? }\end{array}$ & 300 & 75 & 80 & 20 & 20 & 5 \\
\hline $\begin{array}{l}\text { 2. Yakınmalarınızı, daha önce geçirdiğiniz hastalıkları, } \\
\text { gördüğ̈̈nüz tedavileri ve tıbbi müdahaleleri, eğer } \\
\text { varsa halen kullandığınız ilaçları ve sağlığınızla ilgili } \\
\text { bilgileri mümkün olduğunca eksiksiz ve doğru } \\
\text { vermeniz gerektiğini biliyor musunuz? }\end{array}$ & 352 & 88 & 40 & 10 & 8 & 2 \\
\hline $\begin{array}{l}\text { 3. Hekim tarafindan belirlenen sürelerde kontrole gelme } \\
\text { ve tedavinin gidișatı hakkında geri bildirimlerde } \\
\text { bulunmanız gerektiğini biliyor musunuz? }\end{array}$ & 360 & 90 & 24 & 6 & 16 & 4 \\
\hline $\begin{array}{l}\text { 4. Randevu tarih ve saatlerine uymanız ve değişiklikleri } \\
\text { ilgili yere bildirmeniz gerektiğini biliyor musunuz? }\end{array}$ & 372 & 93 & 24 & 6 & 4 & 1 \\
\hline $\begin{array}{l}\text { 5. İlgili mevzuata göre öncelik tanınan hastalar ile diğer } \\
\text { hastaların ve personelin haklarına saygı göstermeniz } \\
\text { gerektiğini biliyor musunuz? }\end{array}$ & 376 & 94 & 24 & 6 & 0 & 0 \\
\hline $\begin{array}{l}\text { 6. Personele sözlü ve fiziki } \\
\begin{array}{l}\text { saldırıya } \\
\text { davranışlarda bulunnelik } \\
\text { musunuz? }\end{array}\end{array}$ & 392 & 98 & 8 & 2 & 0 & 0 \\
\hline $\begin{array}{l}\text { 7. Haklarınızın ihlal edildiğinizi düşündüğünüzde veya } \\
\text { sorun yaşadığınızda hasta hakları birimlerine } \\
\text { başvurabileceğinizi biliyor musunuz? }\end{array}$ & 280 & 70 & 112 & 28 & 8 & 2 \\
\hline Ortalama & 347.4 & 86.9 & 44.6 & 11.1 & 8 & 2 \\
\hline
\end{tabular}

Hastaların en çok \%98 oranında personele sözlü ve fiziki saldırıya yönelik davranışlarda bulunmaması, \%94 oranında ilgili mevzuata göre öncelik tanınan hastalar ile diğer hastaların ve personelin haklarına saygı gösterilmesi ve \%93 oranında randevu tarih ve saatlerine uyulması ile ilgili sorumlulukları bildikleri saptanmıştır. Hastaların en az $\% 70$ oranında hasta hakları birimine başvuru yapma, \%75 oranında sağlık kurum ve kuruluşlarının kural ve uygulamalarına uygun davranma ve katılıme bir yaklaşımla teşhis ve tedavi ekibinin bir parçası olma ve \%88 oranında kullanılan ilaç bilgilerini hekime eksiksiz bir şeklide bildirme ile ilgili sorumlulukları bildikleri saptanmıştır (Tablo 4). 


\section{TARTIŞMA}

Araştırmaya katılan hastaların \%51'i hasta haklarından haberdar olduğunu, \%14'ü hastanedeki sağlık çalışanları tarafından bilgilendirildiğini belirtmiştir. Ayrıca konuyla ilgili yasal düzenlemelerden bir tanesi olan Hasta Hakları Yönetmeliğini de hastaların \%55'i bildiğini belirtmiştir. Erciyes Üniversitesinde yatan hastalara ilişkin 2007 yılında Günay ve arkadaşları tarafından yapılan çalışmada; hastaların \%27,6'sı Hasta Hakları Yönetmeliğini bildiği belirlenmiştir. 2006 yılında Kuzu ve arkadaşları tarafından Denizli’de yapılan başka bir çalışmada ise hastaların sadece \%9'u HHY'den haberdar olduğu belirlenmiştir. Yapılan bu araştırmada hastaların Hasta Hakları Yönetmeliğini bilme durumları diğer araştırmalara oranla daha yüksek çıkması; bu araştırmanın güncel olmasıyla ilgili olabilir dolayısıyla Türkiye'de sağlıkta dönüşüm projesinden sonra sağlıkta birçok gelişme olmuş ve sağlık hizmetlerin halka ulaşımı daha rahat olmuştur. Kısacası yapılan araştırmalar yaklaşık 15-20 yıl önce olduğu için bu konuda şimdiye kadar hastaların dolayısıyla halkın daha da bilinçlendiğini söyleyebiliriz. Ayrıca araştırmaya katılan hastaların büyük bir kesimin eğitim seviyesinin iyi olduğu ve genç kesimden oluştuğuyla da ilişkilendirilebilir.

Araştırmanın sonuçlarına göre hastaların bilgi düzeylerinin en yüksek olduğu hasta hakk1 \%95 ile refakatçi ve ziyaretçi hakkıdır. 2011 yılında Ünsal ve arkadaşları tarafından yapılan araştırmada hastaların \%97,8'i ziyaretçi ve refakatçi hakkını en iyi bildikleri hak olduğunu, 2009 yılında Özer ve arkadaşları tarafından yapılan araştırmada ise hastaların \%79,4'ü ziyaretçi hakkı \%82,9’u refakatçi hakkı olduğunu saptamıştır. Hastaların \%86'sı rıza dışı hiçbir tıbbi müdahalenin yapılamayacağı hakkını bilmektedirler. 2011 yılında Ünsal ve arkadaşları tarafından yapılan çalışmada da hastaların \%92,3'ü müdahale için rızanın alınması gerektiği belirlenmiştir. Hastaların büyük bir oranı insani değerlere saygı ve tedaviyi reddetme hakkı olan hasta haklarını bildiği tespit edilmiştir. Bu sonuçlara paralel olarak Ünsal ve arkadaşları 2011 yılında yaptıkları araştırmaya göre hastaların \%90,1'i saygı görme hakkı ve \%70’i tedaviyi reddetme hakkı olduğunu saptamıştır. 2004 yılında Eksen ve arkadaşları tarafından yapılan araştırmada ise hastaların \%86,5'i il sırada bilinen hasta hakları saygı görme, özen ve ihtimam gösterilerek sağlık hizmetleri alma haklarının olduğunu ayrıca en iyi bildikleri hasta hakkının da hasta rızası alınmadan tıbbi müdahale yapılamaması olduğunu belirtmişlerdir.

Yaptığımız araştırmanın sonuçlarına baktığımızda hastaların sağlık çalışanları tarafından çok az (\%14) bir oranda bilgilendirildiğini görmekteyiz. Bu sonuca benzer olarak Ünsal ve ark. (2011, s. 27-40); Özer vd., (2009, s. 19-28) yaptıkları araştırmalarda hastaların çok az 
bilgilendirildiğini belirtmişlerdir. Hastaların \%74'ü sağlık kuruluşunu seçme ve değiştirme hakkına sahip olduğunu bilmektedir. Buna karşın personeli tanıma, değiştirme ve seçme hakkını ise sadece \%52'isi bilmektedir. Literatürde ilgili araştırmalara baktığımızda 2004 yılında Eksen ve arkadaşları tarafından yapılan bilimsel çalışmada; hastaların 551'i sağlık hizmeti veren doktorların ve diğer sağlık çalışanların isimlerini, görevlerini ve unvanlarını öğrenmeye, seçmeye veya değiştirme haklarının olduğunu bildirmiştir. Hastaların genel olarak az bilgi sahibi olduğu bu hak konusunda ilgili kurumların devreye girip eğitim ve bilinçlendirme çalışmalarını yapmaları ve bu sayede hastaların bilgilendirilebileceği düşünülmektedir.

Sağlık hizmetlerinin sunulduğu kurumlarda karşımıza çıkan en önemli haklarda bir tanesi de hasta mahremiyetidir. Doktorların hasta haklarıyla ilgili bilgi düzeylerine yönelik 2010 yılında yapılan bir çalışmada; hekimlerin \%90,7'si hastanın mahremiyetine saygı gösterilmesi gerektiğini belirtmiştir. Demircan ve diğerleri tarafından (2008, s. 14) hemşirelik öğrencilerin hasta haklarıyla ilgi bilgi düzeylerini belirlemeye yönelik çalışmada; Hemşirelik okuyan öğrencilerin en az bildiği hasta hakkı mahremiyete sayg1 olduğu belirlenmiştir. Bu denli önemli araştırmalar konusu olan mahremiyete saygı konusunda araştırma grubumuz \%84 ile bilgi sahibi olduğu tespit edilmiştir.

Hastaların \%81'i güvenli ortamda sağlık hizmeti alma hakkını bildiğini belirtmiştir. Ünsal ve ark (2011) çalışmasında \%71,4, Özer ve ark. (2009) çalışmasında \%73 ve Eksen ve ark (2004) çalışmasında \%84,7 olduğu belirlenmiştir. Yaptığımız araştırma sonucu benzer çalışmalarla desteklenmektedir. Ayrıca araştırmaya katılan hastaların \%76'sı dini vecibelerini yerine getirme ve dini hizmetlerden faydalanabilme hakkı olduğunu bilmektedir. Ünsal ve ark (2011) çalışmasında hastaların \%73,6'sı ve Özer ve ark. (2009) çalışmasında hastaların \%74'ü dini vecibeleri yerine getirme hakkı olduğu bilgisi paylaşılmış olup sonuçlar verilerimizle örtüşmektedir. Araştırmamıza katılan hastaların \%83'ü müracaat, şikâyet ve dava hakkı olduğunu bilmektedir. 2011 yılında Ünsal ve arkadaşları tarafından yapılan çalışmada hastaların \%78'i hastanelerde şikâyet ve dava hakkının olduğu tespitinde bulunulmuştur.

Araştırmaya katılan hastaların sadece \%44'ü adalet ve hakkaniyete uygun olarak sağlık hizmetlerinde faydalanma hakkı olduğunu bilmektedir. Ünsal ve arkadaşlarının 2011 yılında yaptığı çalışmada bu oran \%70,3 bulunmuştur. Katılımcıların bu soruya politik yaklaştığı düşünülmektedir. Ayrıca Eğitim ve Araştırma Hastanenin Diyarbakır'ın en büyük ve yoğun hastanelerinden bir tanesi de olması ve anketin pandemi (Covid-19) sürecinde uygulanmasıyla da açıklanabilir. Hekim, hemşire ve hastaların hastanede uygulanan hasta haklarını 
değerlendirmeleri adlı bir başka çalışmada; "Devlet hastanesindeki başvuran hastaların hasta hakları bilgi düzeyleri, üniversite hastanelerine başvuran hastalara göre daha iyi olduğu saptanmıştır." Bu sonuçların araştırmamızın sonuçlarıyla da örtüştüğü görülmektedir. Eğitim ve Araştırma Hastanesinin Hasta Hakları Birimi, hastanenin girişine yakın bir yerde olduğu için hastaların büyük birçoğunun birimden haberdar olmuştur ki bu da verilerin sonucundan anlaşılmaktadır. Araştırma Grubunun eğitim seviyesinin yüksek olması ve genç hastaların ağırlıkta olması hak bilme ve sorumluluk noktasında daha önceki benzer çalışmalardan daha iyi olmasına vesile olmuş olabilir. Araştırmamızın güncel olması 2004, 2007, 2009 ve 2011 yıllarında yapılan benzer araştırmalardan daha yüksek oranda hasta hak ve sorumlulukların bilinmesine vesile (sebebiyet) olmuş olabilir. Sonuçta gün geçtikçe sağliktaki gelişmelerle beraber hastaların bilinç seviyesinde de pozitif yönde değişimler olmaktadır.

\section{SONUÇ VE ÖNERILLER}

Hastalar üzerinde yaptı̆̆ımız bu araştırmaya göre; ortalama olarak hastaların hasta haklarını iyi düzeyde bildiği, sorumluluklarını da yüksek düzeyde bildikleri saptanmıştır. Hastaların hasta hakları konusunda sağlık çalışanları tarafından istendik düzeyde bilgilendirilmediği araştırma sonuçlarından anlaşılmaktadır.

Hastaların en iyi bildiği hak; "ziyaret ve refakatçi hakkı" olduğu, en iyi sorumluluk ise; "sağlık personeline fiziki veya sözlü herhangi bir saldırıda bulunulmaması" olduğu görülmektedir. Hasta haklarının ihlali durumunda kişinin hasta hakları birimine başvurması, kişinin kendi sorumluluğundadır. Hastaların en az bildikleri sorumluluğun bu olduğu görülmektedir. $\mathrm{Bu}$ sorumluluğun kişilerde istendik (daha yüksek) düzeye gelebilmesi için hastane yönetimi ve hasta hakları birim personeli tarafından hastanenin belirli yerlerine (hastaların rahatça görebileceği yerler) bilgilendirici afiş, broşür, pankart vs. asılmalı veya gerektiğinde broşürlerin hastalara tek tek dağıtılması önerilmektedir.

Araştırmanın sonuçlarından yola çıkarak ayrıca şu önerilerde bulunmak mümkündür:

- Hasta haklarıyla ilgili sağlık çalışanların eğitilmesi ve hastalara mümkün oldukça bu alanla ilgili bilgi vermeleri durumunda hastaların daha da bilinçlenebileceği düşünülmektedir.

- Nitelikli, duyarlı, iletişimi güçlü ve empati yeteneği olan personellerin Hasta Hakları Birimlerinde istihdamları sağlanmalıdır.

- Hastanede çalışan tüm personellerin hasta hakları konusunda eğitilesi ve aldıkları eğitimle hasta/hasta yakınlarına yardımcı olmaları-yol göstermeleri sağlanmalıdır. 
- Hasta Hakları Yönetmeliğinde geçen; hasta hak ve sorumlulukların hastalar tarafından görülebilecek yerlerde asılması yönetim tarafından veya ilgili personel tarafından sağlanmalıdır.

- Gerek Bakanlık tarafından gerek hastane yönetimi ve personeli tarafından gerekse de kitle iletişim araçları vasıtasıyla toplumun tamamı hasta hak ve sorumlulukları hususunda bilgilendirilmelidir.

- Sağlık kurum ve kuruluşların hastalara istendik düzeyde hasta hak-sorumlulukları bilgilendirmesi maksadıyla ilgili personelleri iyi yetiştirmeleri ve personellerin hizmet içi eğitim almaları sağlanmalıdır.

\section{KAYNAKÇA}

Bostan, S. (2007). Sağlık çalışanlarının hasta haklarına yönelik tutumlarının araştırılması: Farabi hastanesi örneği. Hacettepe sağlık idaresi dergisi, 10(1), 1-18.

Bozkuş, A. (1997). Türkiye'de ve dünyada hasta hakları. Yüksek lisans tezi. Osman gazi üniversitesi sağlık bilimleri enstitüsü deontoloji anabilim dalı, Eskişehir.

Civaner, M., \& Okuyan, A. Z. (1999). Tıbbi Etik İhlalleri. Türk Tabipleri Birliği Yayınları.

Çotur, H. (2013). Hasta hakları ve Kocaeli gölcük Necati çelik devlet hastanesi personeli ile hastaneye müracaat eden hastaların hasta hakları konusundaki bilgilerinin ölçülmesi. Yüksek lisans tezi, Ufuk üniversitesi sosyal bilimler enstitüsü, Ankara.

Demircan, T., Özer, F. G., \& Beydağ, K. D. (2008). Sağlık yüksekokulu öğrencilerinin hasta hakları konusundaki bilgi düzeyleri. Fırat sağlık hizmetleri dergisi, 3(8), 3-16.

Demirhan, A. (1996). Tıbbi deontoloji ve genel tıp tarihi. Güneş Nobel Yayınları.

Eksen, M., Karadağ, N., Işıkay, Ç., Karakuş, A., Seyhan, D., \& Karanlık, M. (2004). Hastaların hasta hakları konusundaki bilgi düzeylerinin belirlenmesi. Uluslararası insan bilimleri dergisi, 1(1), 1-12.

Engin, Z. Ü. (2014). Birey kavramının gelişimi ve insan hakları. Journal of ıstanbul university law faculty, 72 (1) , 201-217.

Günay, O., Naçar, M., Horoz, D., Özdemir, M., Çıtıl, R., Mutlu, S. S., Borlu, A., \& Akpınar, F. (2007). Erciyes üniversitesi hastanesi'nde yatan hastaların hasta hakları konusundaki bilgi düzeyi. Erciyes medical journal, 29(4), 303-311.

Hatırnaz, G. (2007). Özel hastanelerin hukuki sorumluluğu. Seçkin Yayıncılık.

Hatun, Ş. (1999). Hasta hakları. İletişim Yayınları.

Hasta Hakları Yönetmeliği (HHY). (1998). Resmi Gazete, 10.08.1998. Sayı:23420.

Hasta Hakları Yönergesi (2020). "Sağlık Tesislerinde Hasta Hakları Uygulamalarına İlişkin Yönerge”. www.saglik.gov.tr. Erişim tarihi: 04.05.2021 
Johnstone, M. S. (1989). Professional ethics and patient rights. Nursing forum, 24/29 - 34.

Kuzu, N., Ergin, A., \& Zencir, M. (2006). Patients' awareness of their rights in a developing country. 120/ 290-296.

Oğuz, Y. N. (1997). Hasta hakları alanında gelişmeler ve değişen değerler. Türkiye klinikleri tıbbi etik, 5:50-55.

Özcan, C. (2010). Bir devlet hastanesi örneğinde hasta hakları uygulamalarının değerlendirilmesi. Bilim uzmanlığı tezi, Hacettepe üniversitesi sosyal bilimler enstitüsü, Ankara.

Özer, N., Özlü, Z. K., \& Sarıtaş, S. (2009). Cerrahi kliniklerde tedavi gören hastalar haklarını biliyorlar mı?. Atatürk Üniversitesi HYO Dergisi, 12(4):19-28.

Özlü, T. (2005). Hasta haklarl. Timas Yayınları.

Tengilimoğlu, D., Işık, O., \& Akbolat, M. (2020). Sağlık işletmeleri yönetimi. Nobel Akademik Yayıncılik.

Ünsal, A., Bulucu., G. D., Kura, E., \& Ercan, Y. (2011). Poliklinik hizmeti alan hastaların hasta haklarına ilişkin bilgi düzeyleri. Fırat sağllk hizmetleri dergisi, 6(17), 27-40. 